\title{
Aplikácia Kornéliovho zákona o vrahoch a travičoch (lex Cornelia de sicariis et veneficis)
}

\author{
Martin Gregor
}

Právnická fakulta, Univerzita Komenského v Bratislave

Kontaktnie-mail:martin.gregor@flaw.uniba.sk

\begin{abstract}
Application of the Cornelian Law on Assassins and Poisoners (lex Cornelia de sicariis et veneficis)
\end{abstract}

\begin{abstract}
:
The submitted contribution deals with application of the Cornelian Law on Assassins and Poisoners, which reacted on the sinister social phenomenon elicited by internal crisis of the republic in the form of a rapid increase of violent criminal activity. With a special consideration the article devotes to individual facts of the crimes which the act embedded. Besides the commission of a wilful murder, the article analyses also arming for the purpose of a wilful murder perpetration, reaching of unfair conviction of an innocent person to capital punishment due to corruption, machinations, or false testimony, or eventually setting the blaze with the intention to kill persons in a blazing building. At the same time, the article devotes also to recourse for poisoning which was considered as a special manner of commission of a wilful murder. Last, but not least, the article focuses on later extension of the force of this law to further criminal activity, e. g. castration, illegal circumcision, mixing of love-philtres, and administration of dangerous medicine.
\end{abstract}

Keywords: lex Cornelia de sicariis et veneficis; wilful murder in the Roman Law; Roman criminal law

Kl’účové slová: lex Cornelia de sicariis et veneficis; úkladná vražda v rímskom práve; rímske trestné právo

DOI: $10.14712 / 2464689 X .2020 .3$

Financování: Tento príspevok bol vypracovaný ako výstup z grantu APVV č. 17-0022 „Rímsko-kánonické vplyvy na slovenské verejné právo“. 
Lucius Cornelius Sulla využil svoju diktátorskú právomoc na presadenie viacerých dôležitých zámerov v oblasti legislatívy. Jeho zákony (leges Corneliae) tvoria pomerne rozsiahly komplex právnych predpisov. ${ }^{1} \mathrm{Z}$ hl'adiska ich početnosti sú typicky prirovnávané k Augustovým zákonom (leges Iuliae). Výrazne ovplyvnili nielen oblast' ústavného práva, no zásadným spôsobom poznamenali aj trestnoprávnu úpravu. Do tohto rámca patril aj tzv. Kornéliov zákon o vrahoch a travičoch (lex Cornelia de sicariis et veneficis) z roku 81 pred n. 1 .

Predstavuje jeden z klúčových predpisov rímskeho trestného práva a hlavný prameň právnej úpravy trestných činov proti životu a zdraviu. Pred jeho vydaním postihovali vraždu človeka predovšetkým král'ovské zákony druhého rímskeho král'a Numa Pompilia (či údajne samotného Romula), ${ }^{2}$ zásadnejšiu úpravu však možno nájst' až v Zákone XII tabúl'. ${ }^{3}$ V odbornej literatúre sa pritom vyskytuje názor, že v staršom rímskom práve bola akákol'vek vražda človeka vnímaná ako parricidium, teda skutok, ktorý neskôr nadobudol význam otcovraždy, resp. vraždy blízkeho príbuzného. ${ }^{4}$ Až neskôr zrejme došlo k užšej špecifikácii jednotlivých trestných konaní. Vražda človeka napokon nemala v klasickej latinčine dlho svoj vlastný ekvivalent, čo je zaujímavejšie o to viac, kol'ko termínov bolo známych pre kulpózne zabitie (occidere, necare). Pojem homicidium sa vyskytol až v cisárskom období. ${ }^{5}$ Tento zákon sa mal teda primárne vzt'ahovat' na travičstvo a násilnú vraždu človeka prostredníctvom zbrane (bodnej, sečnej, či strelnej).

Ked’že znenie tohto zákona sa nám zachovalo iba v krátkych úryvkoch rímskych právnikov, ktoré zachytili justiniánski kompilátori (čo je napokon osudom drvivej väčšiny rímskeho republikánskeho zákonodarstva), tento článok sa pokúsi o jeho rekonštrukciu na základe právnych a neprávnych prameňov. Zameria sa však nielen na jeho vlastný obsah, ale aj na neskoršiu aplikáciu tohto zákona v priebehu principátu, pre ktorú bolo charakteristické extenzívne rozširovanie jeho pôsobnosti na rad d'alších protiprávnych konaní (často kurióznych a dovtedy neupravených skutkov, akým bola výroba nápojov lásky a kastrácia, ktorých styčné body pri určitej miere fantázie nájde nejedna duša). Z pertraktovaného textu zároveň vyplýva, že tejto analýze podrobíme výlučne hmotnoprávnu rovinu tohto zákona, pričom v procesnoprávnej rovine sa obmedzíme na upozornenie, že rozhodne nebola zanedbatel'ná. ${ }^{6}$

1 Historické hl’adisko Sullovho zákonodarstva analyzuje: LANGE, L. Römische Alterthümer. Dritter Band: Erste Abteilung. Berlin: Weidmannsche Buchhandlung, 1876, s. 165. Podobne: MOMMSEN, Th. The History of Rome. III. Volume. Translated by W. Dickson. London: Richard Bentley, 1867, s. 359-375. Prehl'ad Sullových zákonov ponúka klasické dielo Rotondiho: ROTONDI, G. Leges publicae populi Romani. Milano: Società editrice Libraria, 1912, s. 349-363.

2 „Je zvláštne, že nevymeral nijaký trest proti otcovrahom, ale každé zabitie človeka označoval ako otcovraždu, ako keby už sám zločin vraždy bol prekliatím, no otcovražda priam nemožnost'ou.“ (Plut. Rom. 22). Pozri: PLUTARCHOS. Životopisy slávnych Grékov a Rimanov. Prvý zväzok. Bratislava: Kalligram, 2008, s. 70. Zároveň „muž mohol prepustit’ ženu, ak otrávila diet’a...“. Pozri: Tamtiež.

3 Zo Zákona XII tabúl' $(8,24)$ sa v tomto kontexte zachovala veta: Si telum manu fugit magis quam iecit, aries subiicitur. „Ak mu zbraň skôr z ruky vykĺzla, než by ju bol hodil, nech je na miesto neho daný baran.“

4 Pozri literatúru citovanú v: GREGOR, M. - BELEŠ, A. Hmotnoprávna stránka trestného činu otcovraždy (parricidium) v rímskom práve od najstarších čias po vznik principátu. Acta Facultatis Iuridicae Universitatis Comenianae, 2018, roč. 37, č. 1, s. 60-61.

5 MOMMSEN, Th. Römisches Strafrecht. Leipzig: Verlag von Duncker \& Humblot, 1899, s. 613.

6 KUNKEL, W. Untersuchungen zur Entwicklung des römischen Kriminalverfahrens in vorsullanischer Zeit. München: Verlag der Bayerischen Akademie der Wissenschaften, 1962, s. 38 a nasl. 


\section{Charakteristika a dôvody vydania zákona}

V dôsledku občianskej vojny medzi Luciom Corneliom Sullom a Gaiom Mariom razantne stúplo páchanie násilnej trestnej činnosti (vrátane vrážd a podpal’ačstva). Po Sullovom vít’azstve boli navyše vyhlásené proskripcie, ktoré predstavovali legalizované zabíjanie politických odporcov priamo na uliciach, pričom pri vraždení nezriedka došlo aj k omylu. ${ }^{7}$ Tieto udalosti vyvolali u rímskych občanov pocit strachu o vlastný život a bezpečnost'. Aj po stabilizácii Sullovej diktatúry sa v Ríme stále nachádzalo množstvo demobilizovaných vojakov a bezprizorných Italov bez domova. ${ }^{8} \mathrm{Na}$ základe týchto okolností sa javilo ako nevyhnutné, aby bol prijatý osobitný zákon o vraždách, ktorý niesol meno svojho navrhovatel'a ako lex Cornelia de sicariis et veneficis. Z politických dôvodov sa však nevzt'ahoval na prípady vrážd, ktoré boli spáchané počas proskripcií. ${ }^{9}$ U týchto vrahov bola trestná zodpovednost' vylúčená, čo bolo samou podstatou ich realizácie.

Kornéliov zákon možno pokladat' za jeden z najvýznamnejších prameňov rímskeho trestného práva. Z historického hl'adiska predstavoval prvý predpis, ktorý stíhal vraždu človeka od čias Zákona XII tabúl'. ${ }^{10}$ Uvedená úprava postačovala dovtedy, kým sa tento trestný čin páchal relatívne sporadicky a verejná mienka ho zakaždým odsúdila. Obdobie politických nepokojov si však vyžiadalo prijatie novej legislatívy, ktorá by reagovala na úpadok morálnych štandardov spoločnosti a devalváciu hodnoty l'udského života v dôsledku mocenských zápasov, čoho prejavom bolo aj bezostyšné pôsobenie rôznych nájomných vrahov a banditov. ${ }^{11}$

Na druhej strane je nevyhnutné zdôraznit', že Rimania chápali medze dovoleného usmrtenia človeka - bez súdu - ovel’a širšie, než je tomu v súčasnosti. Okrem prípadu nutnej obrany bolo možné oprávnene zavraždit' akéhokol'vek nepriatel'a štátu (napr. na základe senatusconsultum ultimum), či vyhnanca bez právnej ochrany, ktorý porušil uložené zapovedanie ohňa a vody (aquae et ignis interdictio). Zabitie diet'at’a spadalo pod ius vitae necisque otca. ${ }^{12}$ Rozsudky smrti v rodine väčšinou vynášal domáci súd (iudicium domesticum). Dokonca ešte aj po prijatí leges Corneliae sa ustálil d’alší dôvod legálneho zabi-

7 Živo ich opisuje napríklad Plutarchos v Sullovom životopise (31): „Vtedy Sulla začínal vraždit’ a krvavým činom nebolo v meste konca. Tých, čo doteraz nemali so Sullom nič spoločné, odstraňovali ich osobní nepriatelia, pretože Sulla dovol'oval svojim prívržencom aj také ukrutnosti, aby sa im odvd'ačil... Ba nepoškvrnené vraždami neostali ani chrámy bohov, ani pohostinské či otcovské kozuby. Mužov zabíjali pred zrakmi manželiek a deti v náručí matiek. Tí, čo padli za obet' hnevu alebo pomste, boli v mizivej menšine oproti tým, čo boli vraždení kvôli majetku.“ Pozri: PLUTARCHOS, c. d., s. 918-919. Z odbornej spisby k tomu pozri bližšie: HEFTNER, H. Der Beginn von Sullas Proskriptionem. In: TYCHE - Contributions to Ancient History, Papyrology and Epigraphy, 21. Bund. Wien: Holzhausen Verlag, 2007, s. 33-52.

8 KEAVENEY, A. Sulla: The last republican. New York: Routledge, 2005, s. 146.

9 To dokazuje napríklad zmienka v Suetoniovi: „Ked’ (Caesar) viedol vyšetrovanie proti úkladným vrahom, zaradil medzi nich aj tých, čo za proskripcií dostali peniaze zo štátnej pokladnice za hlavy rímskych občanov, hoci podl'a Corneliovho zákona sa u nich mala urobit’ výnimka.“Jeho pokus však nebol úspešný (Suet. Iul. 11). Pozri: SUETONIUS, Gaius Tranquillus. Životopisy rímskych cisárov. Bratislava: Vydavatel'stvo Spolku slovenských spisovatel'ov, 2010, s. 21.

10 Tento trestný čin bol však primárne upravený v král’ovských zákonoch Numa Pompilia, ktoré boli ešte staršie ako Zákon XII tabúl'. K tomu pozri: GAUGHAN, J. Killing and the king: Numa’s murder law and the nature of monarchic authority. Continuity and Change, 2003, roč. 18, č. 3, s. 330 a nasl.

11 KÖSTLIN, CH. R. Die Lehre vom Mord und Todtschlag. Erster Theil: Die Ideen des Römischen Rechts. Stuttgart: J. B. Metzler'schen Buchhandlung, 1838, s. 105.

12 ARJAVA, A. Paternal Power in Late Antiquity. Journal of Roman Studies, 1998, roč. 88, s. 153. 
tia, ked’ bol dcérin milenec prichytený in flagranti jej otcom na základe Júliovho zákona o trestaní cudzoložstva. Napokon aj vlastník mohol pôvodne zabit' svojho otroka. Uvedené výnimky prirodzene ovplyvňovali koncept vraždy v rímskom práve. ${ }^{13}$

S rôznymi modifikáciami ostal účinný počas celého obdobia cisárstva. ${ }^{14}$ Suetoniova cynická zmienka o eventuálnom Júliovom zákone o vražde a travičstve je vo všeobecnosti pokladaná za nedopatrenie. ${ }^{15}$ Naopak, pomerne skoro sa Kornéliov zákon stal univerzálnym predpisom vo vzt'ahu k akémukol'vek usmrteniu človeka. Túto skutočnost' dokazuje už výrok rečníka Quintiliána pri vysvetl'ovaní významu slov: „Každého, kto spácha vraždu s akoukol'vek zbraňou, nazývame sicarii“",16 teda bez ohl'adu na hmotný predmet útoku.

\section{Skutkové podstaty Kornéliovho zákona}

V siedmej knihe spisu „O úrade prokonzula“ (De officio proconsulis) Ulpianus odkazuje na prvú kapitolu Kornéliovho zákona. Podl'a neho sa mala zaoberat' úkladnou vraždou, ktorú páchatel' vykonal so sečnou alebo bodnou zbraňou (sicarii). ${ }^{17}$ Svoje označenie nadobudol tento trestný čin podl'a svojsky zakrivenej dýky z Trácie, ktorá bola pre páchatel'ov tohto druhu charakteristická. Túto interpretáciu potvrdzujú tak justiniánske Inštitúcie, ${ }^{18}$ ako aj Izidor zo Sevilly. ${ }^{19}$ Údajne svoj pôvodný názov získala podl'a zvolania gladiátora (Sic ha), ktorému sa v boji ohol krátky meč, no napriek tomu chcel pokračovat' v zápase. ${ }^{20}$ S touto dýkou Rimania prišli do kontaktu už v časoch angažovania bratov Gracchovcov, ale najväčšiu obl'ubu získala práve po prvej občianskej vojne. ${ }^{21}$ Jej nositel' sa nazýval sicarius. Prípona „-ius“ údajne poukazuje na profesionálny výkon podobnej činnosti, teda nielen na jej náhodnú držbu a použitie. ${ }^{22}$

13 AMIELAŃCZYK, K. Coll. 1.0. De sicariis (et homicidiis casu vel voluntate) czyli krótki wykład o transformacji rzymskiej ustawy przeciwko „nozownikom“. Studia Iuridica Lublinensia, 2013, roč. 19, č. 1, s. $28-29$.

14 REIN, W. Das Criminalrecht der Römer von Romulus bis auf Justinianus. Leipzig: Verlag von K. Köhler, 1844, s. 408.

15 „Ked’ sa vyhovárala, že mu dala menej jedu, aby sa neprezradil zločin, odvetil jej (Nero): No, pravdaže, ja sa bojím Júliovho zákona.“(Suet. Ner. 33). Pozri: SUETONIUS, c. d., s. 211. K uvedenému záveru právnej romanistiky pozri: MOMMSEN, Römisches Strafrecht, s. 615.

16 Quint. 10, 1, 12. Pozri: The Institutio Oratoria of Quintilian. Translation by H. E. Butler. Volume 4. Cambridge (Massachusetts): Harvard University Press, 1968, s. 9.

17 Coll. 1, 3. Pozri: Mosaicarum et Romanarum Legum Collatio. Introduction and Translation by M. Hyamson. London: Oxford University Press, 1913, s. 57.

18 Iust. Inst. 4, 18, 5: ... sicarii autem appellantur a sica, quod significat ferreum cultrum... „... Úkladní vrahovia sa označujú podl'a sica, slova označujúceho železný nôž..."

19 „Vrahovia (sicarius) sa tak nazývajú preto, že sú stále ozbrojení zbraňami, aby boli pripravení spáchat’ zločin. Ide tu o dýku (sica), ktorej názov je odvodený od sekania (secare).“ Isidor. 10, 252. Pozri: The Etymologies of Isidore of Seville. Translation by S. A. Barney. New York: Cambridge University Press, 2006, s. 229.

20 Isidor. 18, 6, 6. Pozri: Tamtiež, s. 362. K tomu aj moderný etymologický výklad: VAAN, M. de. Etymological Dictionary of Latin and the other Italic Language. Leiden: Brill, 2008, s. 561-562.

21 K tomu pozri: HUG, A. Sica. In: Paulys Realencyclopädie der classischen Altertumswissenschaft. Zweite Reihe, Vierter Halbband (Selinuntia - Sila). Stuttgart: Alfred Druckenmüller Verlag, 1923, s. 2184-2185. V prameňoch nachádzame správu o jej častom používaní, napríklad túto dýku použival pri vojenských t’aženiach aj Crassus (Val. Max. 3, 2, 12). Pozri: VALERIUS MAXIMUS. Sammlung merkwürdiger Reden und Thaten. Übersetzt von F. Hoffmann. Stuttgart: J. B. Metzler'sche Buchhandlung, 1828, s. 164.

22 LEUMANN, M. a kol. Lateinische Grammatik. Erster Band: Lateinische Laut- und Formen- Lehre. 5. Auflage. München: C. H. Beck'sche Verlagsbuchhandlung, 1977, s. 299-300. 
Podobný výklad zodpovedá skutočnosti, že uvedená skutková podstata sa zameriavala najmä na postih profesionálnych lúpežníckych skupín, rôznych banditov a d'alších živlov, páchajúcich násilnú trestnú činnost' (latrones). ${ }^{23}$ Moderné romanistické výskumy dokonca bazírujú na tom, že tento zákon sa primárne venoval stíhaniu a eliminácii týchto zločineckých skupín, či jednotlivých gangstrov. Zakotvenie trestného činu úkladnej vraždy v podstate odsúvajú ako druhoradý a čisto náhodný účinok pôsobenia tohto zákona. ${ }^{24}$

V tejto časti zákon stíhal viacero konaní, ktoré spolu síce zdanlivo nesúviseli, avšak v podstate sledovali ten istý ciel' - ochranu života a zdravia rímskych občanov, vrátane zaručenia bezpečnosti vo verejnom priestore. Išlo o:

a) úkladnú vraždu človeka (so zbraňou), ${ }^{25}$

b) nedovolené ozbrojovanie (kto nosil so sebou zbraň za účelom spáchania trestnej činnos-

ti, najmä vraždy alebo lúpeže),

c) podpal'ačstvo,

d) krivé svedectvo na súde, ak malo za následok smrt' nevinného, alebo ju mohlo zapríčinit'.

Zmienku o všetkých uvedených skutkových podstatách uvádzajú Digesta. ${ }^{26}$ Paulove Sentencie vynechávajú z tohto výpočtu podpal'ačstvo, rovnako absentuje aj v Collatio legum, ktoré Sentencie preberá. ${ }^{27}$ Napokon justiniánske Inštitúcie sa zmieňujú len o prvých dvoch podstatách (vražde a nosení zbrane). ${ }^{28}$

\section{Úkladná vražda človeka}

Z hl'adiska štruktúry skutkovej podstaty tohto trestného činu mohol byt' jeho subjektom ktokol'vek (tak slobodný, ako aj otrok). Zákon poskytoval ochranu každej l’udskej bytosti (teda aj cudzincom a cudzím otrokom). ${ }^{29}$ Tak široko stanovený rozsah osôb ihned' vzbudil podozrenie, že ide o výsledok interpolačných zásahov. Typicky to možno demonštrovat' na údajnej stati zo zákona: „Neposlušného syna nemôže otec usmrtit', ale má ho obžalovat' pred prefektom alebo miestodržitel’om. “'30 Ked’že právo zabit’ svojho syna odobral otcovi až zákaz cisára Konštantína, je takmer nemožné, aby podobné ustanovenie obsahoval

23 Cloud sa domnieva, že medzi týmito entitami je významový rozdiel. Kým sicarii predstavovali mestských banditov, ktorí operovali výlučne v Ríme, latrones sa mohli vyskytovat' kdekol'vek inde. K jeho argumentácii pozri: CLOUD, D. Leges de sicariis: The first chapter of Sulla's lex de sicariis. ZSS (Zeitschrift der Savigny-Stiftung für Rechtsgeschichte) - Romanistische Abteilung, 126. Band. Wien - Köln - Weimar: Böhlau Verlag, 2009, s. 118-119.

24 CLOUD, D. The primary purpose of the Lex Cornelia de sicariis. ZSS (Zeitschrift der Savigny-Stiftung für Rechtsgeschichte) - Romanistische Abteilung, 86. Band. Weimar: Verlag Hermann Böhlaus Nachfolger, 1969, s. 259-260.

25 To isté potvrdzujú aj justiniánske Inštitúcie. Pozri: Iust. Inst. 4, 18, 5.

26 D. 48, 8, 1 (Marci. 14 inst.): Lege Cornelia de sicariis et veneficis tenetur, qui hominem occiderit: cuiusve dolo malo incendium factum erit: quive hominis occidendi furtive faciendi causa cum telo ambulaverit: quive, cum magistratus esset publicove iudicio praeesset, operam dedisset, quo quis falsum iudicium profiteretur, ut quis innocens conveniretur condemnaretur.

27 PS 5, 23, 1. Pozri aj Coll. 1, 2.

28 Iust. Inst. 4, 18, 5 .

29 KÖSTLIN, $c$. d., s. 106. Sám Ulpianus pripúšt'a, že sa mohol vzt'ahovat' na otroka i na cudzinca (Coll. 1, 3, 2). Pozri: Mosaicarum et Romanarum Legum Collatio, s. 59.

30 D. 48, 8, 2 (Ulp. 1 de adulter.): Inauditum filium pater occidere non potest, sed accusare eum apud praefectum praesidemve provinciae debet. 
republikánsky zákon. ${ }^{31}$ Podobnými argumentmi namietal napríklad Biondo Biondi prítomnost' otroka $\mathrm{v}$ danom texte. ${ }^{32}$

Modus operandi nebol určený, ale v rámci tejto skutkovej podstaty malo dôjst' k smrti obete násilným konaním. Na vznik trestnosti sa vyžadoval zlý úmysel smerujúci k vražde človeka (dolus). Zákon sa nevzt'ahoval na usmrtenie v dôsledku hrubej nedbanlivosti (culpa lata), napríklad v prípade, ked' drevorubač neupozornil na padajúci strom, ktorý následne usmrtil náhodného okoloidúceho. ${ }^{33}$ Pokus o vraždu sa trestal rovnako ako dokonaný skutok. Dokonca platilo, že „,v Kornéliovom zákone sa úmysel berie ako skutok“ (in lege Cornelia dolus pro facto accipitur). ${ }^{34}$ Spolu s páchatel'om postihoval ten istý trest aj jeho pomocníka za predpokladu, že bolo možné dokázat' jeho zlý úmysel. Na druhej strane zákon uznával aj vylúčenie trestnej zodpovednosti v prípadoch krajnej núdze a nutnej obrany. Dokazuje to napríklad konštitúcia cisára Gordiána, podl’a ktorej: „kto v nebezpečenstve života zabil útočníka alebo niekoho iného, tento skutok nemožno stíhat’ žalobou“. 35

\section{Nedovolené nosenie zbrane}

Nedovolené nosenie zbrane sa pôvodne interpretovalo iba ako postih nezakrytého číhania ozbrojenej osoby s úmyslom niekoho zavraždit' (animus occidendi). Túto skutočnost' potvrdil ešte o 300 rokov neskôr aj reskript cisára Diokleciána, podl'a ktorého: „Ak niekto striehne s mečom z dôvodu, aby zavraždil človeka, je zodpovedný podl’a Kornéliovho zákona o vrahoch rovnako ako ten, ktorý už vraždu spáchal, alebo sa o ňu so zlým úmyslom pokúsil.“" $36 \mathrm{~V}$ procese dokazovania tohto činu bol preto žalobca povinný poukázat' aj na d'alšie skutočnosti, ako napríklad podozrivé správanie žalovaného, jeho prítomnost' na pochybných miestach, alebo poskytol dôkaz o tom, že žalovaný má povest' lúpežníka, či zlodeja. ${ }^{37} \mathrm{Z}$ uvedeného vyplýva vel'mi dôležitá skutočnost', že Sullov zákon nikomu nezakazoval nosit' zbraň na účely vlastnej ochrany, zameral sa na striehnutie za účelom spáchania vraždy. ${ }^{38}$

To potvrdzuje aj Cicerónova reč pro Milone z roku 52 p. n. 1., ktorá vel'mi presvedčivo opísala vtedajšiu právnu úpravu: „Na čo by sme mali svoje družiny? Na čo meče? Určite by ich nebolo dovolené nosit', keby sme ich nesmeli použit’... Zákon mlčky uznáva právo

\footnotetext{
31 MOMMSEN, Römisches Strafrecht, s. 618 (pozn. 3).

32 BIONDI, B. Il diritto romano cristiano II: La guistizia, le persone. Milano: Giuffré, 1952, s. 428.

33 D. 48, 8, 7 (Paul. lib. sing. de publ. judic.): In lege Cornelia dolus pro facto accipitur. Neque in hac lege culpa lata pro dolo accipitur. Quare si quis alto se praecipitaverit et super alium venerit eumque occiderit, aut putator, ex arbore cum ramum deiceret, non praeclamaverit et praetereuntem occiderit, ad huius legis coercitionem non pertinet. Takisto Papinianus v knihe o cudzoložstve zdôraznil, že ,tento zákon (lex Cornelia de sicariis) trestá len vrahov, ktorí zapríčinili smrt’ so zlým úmyslom“. (Coll. 4, 9).

34 D. 48, 8, 7 (Paul. lib. sing. de publ. judic.).

35 C. 9, 16, 2 (Reskript cisára Gordiána Quintianovi).

36 C. 9, 16,6 (Reskript cisára Diokleciána a Maximiána Philiscovi).

37 REIN, $c$. d., s. 409.

38 Je to v súlade s Paulovým názorom v jeho Knihe o Turpilliánskom uznesení senátu (D. 48, 6, 11, 2): Qui telum tutandae salutis suae causa gerunt, non videntur hominis occidendi causa portare. „U osôb nosiacich zbraň na účely ochrany svojej vlastnej bezpečnosti sa nepredpokladá, že by ich nosili s úmyslom niekoho zavraždit'. “ K tomu pozri aj Cicerónovu stat' z jeho reči pro Milone $(4,10)$ : „Je to nepísaný, ale vrodený zákon, ktorý sme sa nenaučili, nečítali, nepočuli, ale zo samej prirodzenosti sme vzali, že ak by náš život upadol v dôsledku úkladov do nebezpečenstva, každý prostriedok na jeho zachovanie sa pokladá za počestný.“ Pozri: Výbor řeči Ciceronových. Svazek prvý. Praha: Alexander Storch, 1885, s. 43.
} 
bránit' sa, lebo okrem samotného zavraždenia človeka, stíha aj nosenie zbrane s úmyslom zavraždit' človeka. Ked’že podstatným je úmysel, nie zbraň, má sa za to, že ten, kto použil zbraň na svoju obranu nekonal s úmyslom zavraždit’ človeka.“39

Až na základe Júliovho zákona o verejnom násilí (lex Iulia de vi publica) došlo k sprísneniu tejto normy na úroveň generálneho zákazu pohybovania sa na verejnosti so zbraňou (cum telo in publico esse). ${ }^{40}$ Kým ciel'om Sullovho zákona bola najmä ochrana obyvatel'ov pred rôznymi profesionálnymi lúpežníkmi a vrahmi, ktorý sa často zakrádali s nekalými úmyslami, Augustov zákon sa usiloval zaviest' poriadok plošným zamedzením ozbrojovania sa na verejnosti.

$\mathrm{Z}$ praktického hl'adiska malo $\mathrm{v}$ tomto kontexte význam definovanie pojmu zbran̆ (telum). Právnik Gaius vo svojom komentári k provinčnému ediktu pod zbraňou rozumel: „veci zo železa, palice, kamene a vôbec všetky veci, ktoré môžu akokol’vek telesne ublížit'“. ${ }^{41} \mathrm{~K}$ tejto definícii sa Gaius vrátil aj v komentári k Zákonu XII Tabúl', kde napísal: „ako zbraň sa zvyčajne označuje predmet vystrelený z luku, ale môže to znamenat' aj čokol'vek, čo sa hádže rukou. Z toho vyplýva, že termín zbrane zahŕn̆a aj kameň, palice a železné predmety. Je to odvodené od toho, čo sa vrhá na dial'ku a je vytvorené z gréckeho

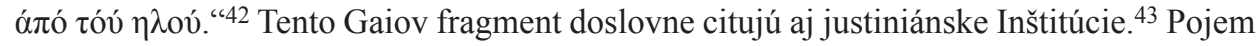
telum totiž pôvodne predstavoval synonymum pre dial'kovú zbraň (určenú na strel'bu), ale v súvislosti s týmto zákonom možno hovorit' o akejkol’vek vražednej zbrani.

\section{Justičná vražda}

Ďalšia kapitola zákona pojednávala o nespravodlivom odsúdení nevinného na smrt'. Jej ciel' sa upínal na potrestanie osoby, ktorej zlomysel'né konanie smerovalo k vyneseniu rozsudku smrti v hrdelnom procese, čo v podstate predstavovalo justičnú vraždu (internecivum iudicium). ${ }^{44}$ Prepojenie s úkladnou vraždou je v tomto prípade jasné: človeka síce nezavraždia, ale jeho smrt' docielia machináciami na súde. Na rozdiel od predošlých skutkových podstát sa však táto úprava zrejme dotýkala len rímskych občanov. Zneužitie spravodlivosti vo vzt'ahu k cudzincovi nespadalo pod úpravu Kornéliovho zákona. ${ }^{45}$

Ako subjekt tohto trestného činu mohol vystupovat' bud' magistrát (senátor), alebo súkromná osoba. Prvý z nich spáchal tento trestný čin, ak prijal peniaze, aby vydal nepriaznivé

39 Cic. pro Mil. 4, 10. Pozri: Výbor řeči Ciceronových, s. 43-44.

40 HARRIES, J. Law and Crime in the Roman World. Cambridge: Cambridge University Press, 2007, s. 107.

41 D. 47, 2, 56, 2 (Gai 13 ad ed. prov.): Furem interdiu deprehensum non aliter occidere lex duodecim tabularum permisit, quam si telo se defendat. Teli autem appellatione et ferrum et fustis et lapis et denique omne, quod nocendi causa habetur, significatur.

42 D. 50, 16, 233, 2 (Gai 1 ad leg. XII tab.): Telum volgo quidem id appellatur, quod ab arcu mittitur: sed non minus omne significatur, quod mittitur manu: ita sequitur, ut et lapis et lignum et ferrum hoc nomine

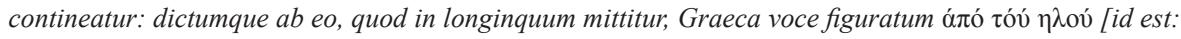
ab eo quod est procul]. ... Podobne právnik Paulus definoval ozbrojencov ako „nielen tých, ktorí majú so sebou zbrane, ale každého, kto so sebou nosí čokol'vek, čím možno fyzicky ubližit‘“. D. 48, 6, 9 (Paul. 7 ad ed.).

43 Iust. Inst. 4, 18, 5.

44 Isidor. 5, 26, 17. Pozri: The Etymologies of Isidore of Seville, s. 123. Pozri aj: KASINEC, R. Justičné omyly a dôsledky s nimi spájané. In: Den právni teorie: Česko-slovenská doktorandská konference o teorii práva. Brno: Masarykova Univerzita, 2014, s. 33.

45 MOMMSEN, Römisches Strafrecht, s. 634. 
rozhodnutie vo vzt'ahu k niekoho životu alebo majetku. ${ }^{46}$ Ked’že v antickom Ríme sa formálne stíhala iba volebná korupcia (ambitus), bolo nevyhnutné postihnút' iným spôsobom sudcovskú korupciu, ktorá sa v praxi vyskytovala. ${ }^{47}$ Jej úprava však bola omnoho prísnejšia. Nespravodlivý rozsudok nad nevinným mohol vyniest' nielen v dôsledku úplatkárstva, ale aj z dôvodu osobnej nevraživosti. ${ }^{48}$ Súkromná osoba sa mohla stat' páchatel'om tohto skutku, ak v rámci svojej výpovede zlomysel’ne poskytla krivé svedectvo. ${ }^{49}$ Ked’že zákon stíhal aktívnu i pasívnu formu korupcie, vrátane najrôznejších intríg a komplotov, ktoré viedli k vyhláseniu trestu smrti, možno ho pokladat’ za univerzálny predpis čeliaci „súdnemu mafiánstvu“ ako takému. ${ }^{50}$

Zavedenie trestnoprávnej zodpovednosti sudcu za vydanie nesprávneho rozhodnutia v dôsledku korupcie v Sullovom zákone sa pokladá za rozšírenie a opätovné potvrdenie niekdajšieho Semproniovho zákona z roku 122 pred n. 1. (lex Sempronia iudiciaria). Na spriaznenost’ týchto zákonov poukázal aj Cicero: „kedysi sa tento zákon nazýval Semproniov, dnes nesie meno podl'a Kornélia““. ${ }^{51}$ Popri pripustení jazdcov do súdnych porôt, ${ }^{52}$ postihoval Semproniov zákon aj úplatkárstvo na súdoch, ked’že „,kvôli tomu mali sudcovia zlú povest'“. ${ }^{53} \mathrm{Na}$ základe neskoršieho lex Livia iudiciaria z roku 91 pred n. 1. možno dokonca predpokladat' existenciu osobitnej poroty na stíhanie zneužitia právomoci sudcu. ${ }^{54}$

\section{Podpal'ačstvo}

Okrem uvedených skutkových podstát stíhal Sullov zákon aj podpal’ačstvo (incendium). Svedčí o tom viacero pramenných dôkazov. Napríklad Ulpianus uvádza, že „Kornéliov zákon ustanovil pre podpal'ačov trest zákazu ohňa a vody“. ${ }^{55}$ Túto spojitost' naznačuje aj reskript cisára Phillippa z roku 244 n. 1., v ktorom sa zaoberal právnou kvalifikáciou podpal'ačstva: „Ak tvrdíte, že Vám náležiaca budova bola zlomysel'ne zničená ohňom, môžete vzniest’ žalobu podl’a Kornéliovho zákona o vrahoch. “56 Napokon sám Marcianus v úvodnom fragmente k tomuto zákonu v Digestách napísal, že „,kto zlomysel’ne založí požiar, zodpovedá podl’a Kornéliovho zákona“. ${ }^{57}$

46 PS 5, 23, 10.

47 GREGOR, M. Právny postih korupcie v období Rímskej republiky. In: 6. slovensko-české stretnutie doktorandov a postdoktorandov. Trnava: Právnická fakulta Trnavskej univerzity, 2018, s. 47 a nasl.

48 REIN, c. d., s. 411, podobne RUDORFF, A. F. Römische Rechtsgeschichte. Erster Band - Rechtsbildung. Leipzig: Verlag von Bernhard Tauchnitz, 1857, s. 86.

49 D. 48, 8, 1, 1 (Marci. 14 inst.): Praeterea tenetur, qui hominis necandi causa venenum confecerit dederit: quive falsum testimonium dolo malo dixerit, quo quis publico iudicio rei capitalis damnaretur: quive magistratus iudexve quaestionis ob capitalem causam pecuniam acceperit ut publica lege reus fieret.

50 SKŘEJPEK, M. Litem suam facere. In: Právněhistorické studie 39. Praha: Karolinum, 2007, s. 15.

51 Cic. pro Cluentio 56, 154. Pozri: The Orations of Marcus Tullius Cicero. Translated by C. D. Young. London: Henry G. Bohn, 1856, s. 169.

52 Plut. C. Grach. 5. Pozri: PLUTARCHOS. Životopisy slávnych Grékov a Rimanov. Druhý zväzok. Bratislava: Kalligram, 2008, s. 622-623.

53 App. b. civ. 1, 22. Pozri: APPIÁNOS. Krize římské republiky (Římské dějiny II - Občanské války). Praha: Svoboda, 1989, s. 33. K tomu pozri aj: ROTONDI, c. d., s. 313-314.

54 Flor. Epit. 2, 5 (III, 17). Pozri: PATERCULUS, Velleius - FLORUS. Dvoji pohled na řimské dějiny. Praha: Baset, 2013, s. 497; App. b. civ. 1, 35. Pozri: APPIÁNOS, c. d., s. 33. Liv. epit. 71. Pozri: LIVIUS. Dějiny VII. Praha: Svoboda, 1979, s. 403.

55 Coll. 12, 5. Pozri: Mosaicarum et Romanarum Legum Collatio, c. d., s. 117.

56 C. $9,1,11$.

57 D. $48,8,1$ (Marci. 14 inst.). 
Uvedené zmienky sú dôkazom o príslušnosti tohto zákona aj vo vzt’ahu k stíhaniu podpal'ačstva. Tento trestný čin dosahoval vysokú mieru závažnosti a k úkladnej vražde bol z toho dôvodu prirovnávaný už v Zákone XII tabúl'. ${ }^{58}$ Zaradením predmetnej matérie do Kornéliovho zákona však vznikla určitá konkurencia vo vzt’ahu k zákonom zamedzujúcim násilie. V dôsledku zapálenia kúrie po smrti Clodia bolo podpal'ačstvo upravené už v Pompeiovom zákone o násilí (lex Pompei de vi) z roku 52 pred n. 1., ktorý sa viazal na zriadenie špeciálneho súdu pre Milóna. ${ }^{59}$ Túto problematiku následne prevzal aj Júliov zákon o verejnom násilí (lex Iulia de vi publica) pravdepodobne vydaným cisárom Augustom v roku 17 pred n. $1 .{ }^{60}$ Marcianus uvádza, že podl'a Júliovho zákona zodpovedala osoba, ktorá „,v rámci zhromaždenia, v dave, alebo počas nepokojov spôsobila požiar““. ${ }^{61}$

Oba druhy zákonov však chránili iné hodnoty. Kornéliov zákon sa usiloval predchádzat’ takým následkom požiaru, ktoré si mohli vyžiadat' obete na životoch. Zákony o násilí sa naopak zaoberali zachovaním verejného poriadku a zabraňovali vzniku nepokojov. Z toho vyplýva, že Kornéliov zákon sa vzt’ahoval na prípady podpal'ačstva, v rámci ktorých úmysel páchatel'a smeroval výlučne proti životu a zdraviu konkrétnych osôb. V tomto kontexte bol požiar vnímaný iba ako prostriedok na úmyselné dosiahnutie smrti (hominis occidendi causa). Jeho teritoriálna pôsobnost' bola obmedzená na mesto Rím a oblast' vo vzdialenosti 1000 krokov od hradieb mesta. ${ }^{62}$ Zákony o násilí trestali založenie požiaru vtedy, ak úmyslom páchatel'a bolo vyvolanie paniky a jej prípadné zneužitie na páchanie násilností. Ich primárnym ciel’om bola ochrana verejného poriadku. Ustanovenia trestného práva však nezasahujú do civilnoprávnych nárokov poškodeného podl’a Akvíliovho zákona.

\section{Travičstvo}

Od úkladnej vraždy, pre ktorú je typické násilie, Rimania často odlišovali travičstvo ako špeciálny spôsob spáchania tohto trestného činu. Vykonáva sa predsa väčšinou potajme a nepozorovane. ${ }^{63} \mathrm{Na}$ základe Marcianovej zmienky možno usudzovat', že táto skutková podstata bola obsiahnutá v piatej kapitole zákona. ${ }^{64} \mathrm{Z}$ významového hl'adiska rímski právnici upozorňovali na skutočnost', že „,kto hovorí o bylinách (venenum), musí dodat',

58 MOMMSEN, Römisches Strafrecht, s. 646. Pozri aj D. 47, 9, 9 (Gai 4 ad leg. XII tab.): „Kto zapáli dom alebo kopu obilia pri dome, bude spútaný, zbičovaný a upálený za živa, ak to spáchal úmyselne a vedome.“

59 Cic. pro Mil. 33, 91. Pozri: Výbor řeči Ciceronových, s. 74.

60 K charakteru tohto zákona pozri: GREGOR, M. Rímsky štát a právo za vlády cisára Augusta. Praha: Leges, 2018, s. 108-111; SKŘEJPEK, M. „Publica“ ad populum romanum rescipit (jak římští právníci chápali slovo ,veřejný“. Právník, 2015, roč. 154, č. 9, s. 711.

61 D. 48, 6, 5 (Marci. 14 inst.): Qui coetu conversu turba seditione incendium fecerit: quique hominem dolo malo incluserit obsederit: quive fecerit, quo minus sepeliatur, quo magis funus diripiatur distrahatur: quive per vim sibi aliquem obligaverit, nam eam obligationem lex rescindit. Podobnú zmienku nájdeme aj v 5. knihe Paulových Sentencií, kde sa uvádza, že podl’a Júliovho zákona zodpovedá ten, „kto založí oheň počas zhromaždenia, v dave alebo v období nepokojov“. (PS 5, 26, 3).

62 REIN, c. d., s. 769; KLEINFELLER, G. Incendium. In: Paulys Realencyclopädie der classischen Altertumswissenschaft. Neue Bearbeitung. Achtzehnter Halbband (Imperium - Iugum). Stuttgart: J. B. Metzlersche Verlagsbuchhandlung, 1919, s. 1244; WÄCHTER, C. G. Lehrbuch des römisch-deutschen Strafrechts. Zweyter Theil. Stuttgart: J. B. Metzler'schen Buchhandlung, 1826, s. 392.

63 Pozri bližšie: ANTALOVÁ, B. Usmrtenie jedom alebo škodlivým liekom v rímskom práve. In: Trestné právo na prahu 3. tisícročia. Košice: Právnická fakulta UPJŠ, 2003, s. 169-175.

64 D. 48, 8, 3 (Marci. 14 inst.): Eiusdem legis Corneliae de sicariis et veneficis capite quinto, qui venenum necandi hominis causa fecerit vel vendiderit vel habuerit, plectitur. 
či má na mysli ich škodlivé účinky (teda jed) alebo dobré, ked’že sem patria aj liečivá“" 65 Podobne právnik Marcianus uvádza, že ,prívlastok škodlivé byliny poukazuje na to, že sa môžu vyskytovat' aj liečivé. Samotný pojem bylín (venenum) je neutrálny.“66 V poňatí Kornéliovho zákona sa lieky a jedy ako výrobky z rastlín často chápu vo vzájomnej súvislosti. Vzt’ahoval sa dokonca na nesprávnu prípravu liekov alebo nápojov lásky ( $p o c u$ lum amatorium). Nemožno sa čudovat', ved' napokon pod vplyvom užívania nápoja lásky postupne ochorel a zomrel aj slávny Lucullus. ${ }^{67}$

Okrem samotného podania jedu (malum venenum), zákon postihoval podla Digest aj jeho prípravu, predaj, alebo držbu, ak predmetná činnost' smerovala k spáchaniu úkladnej vraždy. ${ }^{68} \mathrm{Na}$ túto čast' Kornéliovho zákona sa odvoláva aj Cicero v rámci obhajoby Aula Cluentia (pro Cluentio). Uvádza, že zákon stíhal osobu, ktorá jed pripravila, predala, kúpila, alebo mala vo svojej držbe. Ktokol'vek sa dopustil travičstva, mal byt’ predvedený pred hrdelný súd. Podliehal mu každý muž, žena, prepustenci, či otroci. ${ }^{69}$ Ciel'om tejto úpravy bolo potlačenie nezákonného podnikania s jedmi (venenarii). ${ }^{70}$

\section{Extenzívna aplikácia Kornéliovho zákona}

Pôsobnost' Kornéliovho zákona sa v priebehu času výrazne rozšírila. Začal sa vzt'ahovat' na rôzne trestné činy, ktoré zasahovali do sféry života alebo zdravia človeka, avšak dosial' neboli samostatne upravené. Je nepochybné, že pôvodné znenie zákona s nimi nepočítalo, avšak nariadenia cisárov a neskoršia prax vyvolala potrebu ich zakotvenia. Ako prirodzené sa napríklad javí isté uznesenie senátu, ktoré trestalo zlomysel’né potopenie lode násilným útokom alebo l'st'ou podl'a Kornéliovho zákona o vrahoch za predpokladu, že v dôsledku tejto udalosti nastali straty na životoch. ${ }^{71}$ Medzi nové skutkové podstaty však patrili aj

65 D. 50, 16, 236 (Gai 4 ad leg. XII tab.): Qui venenum dicit, adicere debet, utrum malum an bonum: nam et medicamenta venena sunt, quia eo nomine omne continetur, quod adhibitum naturam eius, cui adhibitum esset, mutat. Cum id quod nos venenum appellamus, Graeci farmakon dicunt, apud illos quoque tam medicamenta quam quae nocent, hoc nomine continentur: unde adiectione alterius nomine distinctio fit. Admonet nos summus apud eos poetarum Homerus: nam sic ait: farmaka, polla men esvla memigmena, polla de lugra [id est: venena multa quidem egregia, multa item noxia]. Aj Aulus Gellius prisúdil pojmu venenum dvojaký zmysel, pričom predstavuje jednak bezpečné, ako aj nebezpečné nápoje (NA 12, 9, 2). Pozri: Die Attischen Nächte des Aulus Gellius. Übersetzt von F. Weiss. Zweiter Band. Leipzig: Fue's Verlag, 1876, s. 152 .

66 D. 48, 8, 3, 3 (Marci. 14 inst.): Alio senatus consulto effectum est, ut pigmentarii, si cui temere cicutam salamandram aconitum pituocampas aut bubrostim mandragoram et id, quod lustramenti causa dederit cantharidas, poena teneantur huius legis.

67 „Zosnul nie pod t’archou starostí, ani nie pre chorobu, ale preto, že ho priotrávil Kallisthenés, jeden z jeho prepustencov. Podával mu tieto nápoje preto, aby si u Luculla získal ešte väčšiu náklonnost', pretože sa domnieval, že mu to môžu zabezpečit'. Avšak namiesto toho Lucullovi pomútili zdravý rozum a celkom ho oň pripravili.“ (Plut. Luc. 43). Pozri: PLUTARCHOS, c. d., s. 769. To potvrdzuje aj Plínius: „Slávny Lucullus bol zavraždený nápojom lásky.“ (Plin. HN 25, 7, 25). Pozri: PLINY. Natural History. Volume VII. Translation by W. H. Jones. Cambridge (Massachusetts): Harvard University Press, 1966, s. 155. D. 48, 8, 1, 2 (Marci. 14 inst.): Et qui hominem occiderit, punitur non habita differentia, cuius condicionis hominem interemit. Podobne už v citovanom fragmente D. 48, 8, 3. Cic. pro Cluentio 54. Pozri: The Orations of Marcus Tullius Cicero, s. 165-166.

MOMMSEN, Römisches Strafrecht, s. 636.

71 D. 47, 9, 3, 8 (Ulp. 66 ad ed.): Senatus consultum Claudianis temporibus factum est, ut, si quis ex naufragio clavos vel unum ex his abstulerit, omnium rerum nomine teneatur. Item alio senatus consulto cavetur eos, quorum fraude aut consilio naufragi suppressi per vim fuissent, ne navi vel ibi periclitantibus opitulentur, legis Corneliae, quae de sicariis lata est, poenis adficiendos: eos autem, qui quid ex miserrima 
rôzne menej tradičné úkony, ako napríklad kastrácia, ktorá znemožňovala d'alšiu reprodukciu muža.

Kastráti boli pomerne vyhl'adávaným druhom otrokov. Podl’a Plínia bola za Seianovho kastráta Paeza zaplatená najvyššia kúpna cena $\mathrm{v}$ histórii rímskeho obchodu s otrokmi. Dosahovala sumu 50 miliónov sesterciov. ${ }^{72} \mathrm{O}$ ich pôsobení na cisárskom dvore sa zachovali správy už zo začiatku tretieho storočia. Slúžili nielen cisárovnej, ale nezriedka zastávali aj úradné funkcie, ba cisár Elagabalus bol údajne „otrokom svojich eunuchov““ ${ }^{73}$ Z finančných dôvodov preto často dochádzalo nielen ku kastrácii malých otrokov, ale dokonca aj slobodných chlapcov.

Staršie právo nereflektovalo tieto praktiky. ${ }^{74}$ Historicky prvým doloženým zákazom kastrovania chlapcov je edikt cisára Domiciána, pričom navyše nariadil, aby sa znížili ceny eunuchov, ktorí ešte ostali u otrokárov. ${ }^{75}$ Ako potvrdzuje Dio Cassius: „hoci sa sám zabával s eunuchom Farinom, avšak ked’že jeho brat Titus tiež preukázal vel'kú zhovievavost' voči eunuchom, kvôli nemu naopak zakázal, aby bol na území Rímskej ríše ktokol'vek kastrovaný. "76 Nehl'adiac na túto motiváciu ešte Ammianus o tri storočia neskôr chválil Domiciána, že pod t’ažkými trestami zakázal komukol’vek v rímskej jurisdikcii kastrovat' chlapcov. ${ }^{77}$

Po Domiciánovi opätovne zakázal kastrovanie všetkých príslušníkov mužského pohlavia aj Nerva. ${ }^{78}$ Až na základe reskriptu cisára Hadriána sa kastrovanie začalo trestat' priamo podl'a Kornéliovho zákona o vrahoch a travičoch. Zmienka o tejto norme sa zachovala v Digestach: „Božský Hadrián napísal v reskripte, že nikoho nemožno vykastrovat', no ak by sa niekto opovážil spáchat' tento zločin, zodpovedal by podl'a Kornéliovho zákona o vrahoch a celý jeho majetok by pripadol v prospech cisárskej pokladnice... Nikto nemá právo vykastrovat' slobodného muža, ba ani otroka, bez ohl'adu na vôl'u poškodeného. Muž, ktorý by dobrovol'ne podstúpil kastráciu, vrátane lekára realizujúceho tento úkon, by bol odsúdený na smrt'،79 Zanietenie tohto cisára pre otázky pohlavného zdravia dopí-

naufragorum fortuna rapuissent lucrative fuissent dolo malo, in quantum edicto praetoris actio daretur, tantum et fisco dare debere.

72 Plin. HN 7, 39. Pozri: PLINY. Natural History. Volume (libri III-VII). Translation by H. Rackham. Cambridge (Massachusetts): Harvard University Press, 1961, s. 593.

73 SHA Alex. 23: „,(Alexander Severus) prepustil všetkých eunuchov zo svojich služieb a nariadil, aby boli k dispozícii jeho manželke ako otroci. Hoci Elagabalus bol otrokom svojich eunuchov, Alexander znížil ich počet a zbavil ich všetkých funkcií v cisárskom paláci, okrem starostlivosti o ženské kúpele." Pozri: The Scriptores Historiae Augustae. Volume II. Translation by D. Magie. Cambridge (Massachusetts): Harvard University Press, 1993, s. 220. O mocenskej pozícii eunuchov na cisárskom dvore sa zmieňuje aj Alex. Sev. 66: „Do žiadneho úradu nemenoval eunucha a dbal na to, aby sa nestali členmi ani jeho rady. Tieto kreatúry spôsobili úpadok cisárstva, lebo kvôli nim žili cisári podl’a zvykov cudzích národov alebo ako perzskí králi a držali ich d'aleko od vlastného l'udu a priatel'ov.“ Pozri: Tamtiež, s. 311.

74 GUYOT, P. Eunuchen als Sklaven und Freigelassene in der griechisch-römischen Antike. Stuttgart: Klett-Cotta, 1980, s. 45-46.

75 Suet. Dom. 7. Pozri: SUETONIUS, c. d., s. 274.

76 Dio. 67, 2, 3. Pozri: Dio's Roman History. Translation by Earnest Cary. Volume VIII. London: William Heinemann, 1925, s. 319.

77 Amm. Marc. 18, 4, 5. Pozri: Ammianus Marcellinus. Volume I. Translation by John Rolfe. Cambridge (Massachusetts): Harvard University Press, 1935, s. 425.

78 Dio. 68, 2, 3. Pozri: Dio's Roman History, s. 363.

79 D. 48, 8, 4, 2 (Ulp. 7 de off. procons.): Idem divus Hadrianus rescripsit: ,, Constitutum quidem est, ne spadones fierent, eos autem, qui hoc crimine arguerentur, Corneliae legis poena teneri eorumque bona merito 
ňa aj jeho d'alší reskript Ninniovi Hastovi, kde uvádza: ,ak niekto rozdrvil semenníky, bude potrestaný rovnako, ako keby ich odrezal s nožom“. ${ }^{80}$ Trestnost' kastrácie podl'a Kornéliovho zákona napokon zakotvilo aj bližšie neurčené uznesenie senátu, ktoré je tiež spomenuté v Digestach. ${ }^{81}$

Kornéliov zákon o vrahoch a travičoch však bol aplikovaný aj v prípade vykonania nedovolenej obriezky. Hoci v staršom práve nepodliehal tento úkon rímskoprávnej regulácii, bol to opät' cisár Hadrián, ktorý údajne nie z dôvodu náboženských predsudkov, ale kvôli určitej podobnosti oboch operácií, postavil vykonanie obriezky na roveň kastrácii. ${ }^{82}$ Po vydaní tohto plošného zákazu Židia údajne protestovali proti rímskej nadvláde. ${ }^{83}$ Hadrianov nástupca Antoninus Pius však ustanovil pre nich výnimku. Nachádzame o tom jasnú zmienku v Digestach: „Podl'a reskriptu božského Pia je len Židom dovolené obrezávat' svojich synov. Ak by to bolo vykonané na niekom, kto k tejto viere nepatrí, bude za podobné konanie potrestaný rovnako, ako v prípade kastrácie. “84 Takejto úprave nasvedčuje aj znenie Paulových Sentencií, ktoré uvádzajú: „Rímski občania, ktorí umožnia sebe alebo svojím otrokom obriezku v súlade so židovským rítom, budú po konfiškácii celého svojho majetku deportovaní na ostrov. Lekár, ktorý vykonal operáciu, musí byt' odsúdený na smrt'." 85

V kontexte týchto zásahov do mužského tela bola spomenutá aj určitá zodpovednost' lekárov za vykonanie dotknutých úkonov. Určité následky ich však mohli postihnút' aj pri podávaní nebezpečných medikamentov. Každý jed alebo liek mal podla predstáv Rimanov spoločný pôvod v spracovaní rastlín. Rozlišovali ich podla pozitívnych alebo negatívnych účinkov. Táto vzájomná blízkost' predurčovala rozšírenie pôsobnosti Kornéliovho zákona na aplikáciu liečiv. ${ }^{86}$ Typickým príkladom je isté uznesenie senátu, ktoré nariadilo potrestat' ženu zodpovednú za usmrtenie svojej pacientky tým, že jej pripravila nápoj na podporu plodnosti. V tomto prípade smrt’ nenastala zo zlého úmyslu, ale kvôli pochybeniu bylinkárky. ${ }^{87}$ Ďalšie uznesenie senátu ustanovilo uloženie trestu podl'a Korné-

fisco meo vindicari debere, sed et in servos, qui spadones fecerint, ultimo supplicio animadvertendum esse: et qui hoc crimine tenentur, si non adfuerint, de absentibus quoque, tamquam lege Cornelia teneantur, pronuntiandum esse. Plane si ipsi, qui hanc iniuriam passi sunt, proclamaverint, audire eos praeses provinciae debet, qui virilitatem amiserunt: nemo enim liberum servumve invitum sinentemve castrare debet, neve quis se sponte castrandum praebere debet. At si quis adversus edictum meum fecerit, medico quidem, qui exciderit, capitale erit, item ipsi qui se sponte excidendum praebuit. " D. 48, 8, 5 (Paul. 2 de off. procons.): Hi quoque, qui thlibias faciunt, ex constitutione divi Hadriani ad ninnium hastam in eadem causa sunt, qua hi qui castrant.

81 D. 48, 8, 3, 4 (Marci. 14 inst.): Item is, cuius familia sciente eo apiscendae reciperandae possessionis causa arma sumpserit: item qui auctor seditionis fuerit: et qui naufragium suppresserit: et qui falsa indicia confessus fuerit confitendave curaverit, quo quis innocens circumveniretur: et qui hominem libidinis vel promercii causa castraverit, ex senatus consulto poena legis Corneliae punitur.

82 MOMMSEN, Römisches Strafrecht, s. 615; pozri tiež: D’ORGEVAL, B. L'empereur Hadrien: ceuvre législative et administrative. Paris: Domat-Montchrestien, 1950, s. 67, s. 324.

83 SHA Hadr. 14, 2. Pozri: The Scriptores Historiae Augustae. Translation by David Magie. Volume I. Cambridge (Massachusetts): Harvard University Press, 1991, s. 45. D. 48, 8, 11 (Modest. 6 reg.): Circumcidere iudaeis filios suos tantum rescripto divi Pii permittitur: in non eiusdem religionis qui hoc fecerit, castrantis poena irrogatur.

85 PS 5, 22, 3.

86 REIN, c. d., s. 427.

87 D. 48, 8, 3, 2 (Marci. 14 inst.): Adiectio autem ista ,veneni mali“ ostendit esse quaedam et non mala venena. Ergo nomen medium est et tam id, quod ad sanandum, quam id, quod ad occidendum paratum est, 
liovho zákona v prípade odovzdania, či predaja prípravku, prášku, alebo masti obsahujúcej bolehlav, resp. pre jeho podobnost' aj rozpuk (cicuta), akýkol'vek druh prilbice (aconitum), mandragory, rozdrvených chrobákov a lariev vo všeobecnosti (pituocampis), s osobitným zdôraznením zákazu jedovatého pl’uzgierika lekárskeho (cantharis). ${ }^{88}$ Trestná zodpovednost' však nastupovala len v prípade neuváženej aplikácie týchto prostriedkov.

\section{Záver}

Účel Kornéliovho zákona o vrahoch a travičoch spočíval v potlačení nežiaducich spoločenských javov, akými bolo napríklad páchanie lúpežných či nájomných vrážd, resp. obchodovanie s jedmi. Z jeho úpravy vyplýva, že úkladnú vraždu bolo možné spáchat' rôznymi spôsobmi: násilne s použitím zbrane; l'stivým pridaním otravy do jedla, či nápoja; alebo dokonca založením požiaru, v dôsledku čoho l’udia uhoreli, resp. im hrozilo nebezpečenstvo udusenia od dymu. Predmetný zákon postihoval každé z týchto konaní osobitne. Vystupuje tu do popredia kazuistický prístup rímskeho zákonodarcu a jednotlivých právnikov k matérii úkladnej vraždy. Preto možno dospiet’ ku konklúzii, že takýto abstraktný pojem v rímskom trestnom práve úplne absentoval, a to i napriek neskoršiemu etablovaniu všeobsažného termínu homicidium. Potrebu jednoznačného zakotvenia tohto trestného činu však Rimania zrejme ani subjektívne nepocit'ovali vzhl'adom na špecifické chápanie vraždy v rámci ich právneho poriadku, ktorý počítal vo viacerých prípadoch $\mathrm{s}$ tzv. legitímnym usmrtením. ${ }^{89}$

Zaujímavou je aj skutočnost', že Kornéliov zákon sa neobmedzil iba na úpravu úmyselného usmrtenia človeka ako takého, avšak pokúsil sa o poskytnutie komplexnej ochrany l'udskému životu. Preto postihoval aj nekalé konanie sudcu, resp. poskytnutie krivého svedectva na súde, ktoré by mohlo viest' k vyneseniu rozsudku smrti nad nevinnou osobou. V dôsledku kauzálneho nexu by predsa došlo v takom prípade k spáchaniu justičnej vraždy. Okrem toho zákon ukladal trest aj za špecifický spôsob prípravy trestného činu úkladnej vraždy, ktorý spočíval v ciel'avedomom striehnutí so zbraňou, či prípadnom vyčkávaní obete s jasným úmyslom spáchat' úkladnú vraždu.

Pri vyhodnotení trestnosti jednotlivých skutkových podstát bol vel'mi dôležitý úmysel páchatel’a, ktorý smeroval k usmrteniu človeka. Jedinú výnimku spod tohto konštatovania predstavovala nedbalá, nezodpovedná, či nekvalifikovaná príprava liečiv alebo iných odvarov, ktoré v konečnom dôsledku mohli privodit' smrt' pacientovi na základe nedbanlivostného zavinenia. Napriek tomu sa predmetné konanie postihovalo trestom podl'a tohto zákona.

Napokon od čias cisára Hadriána sa tento zákon vzt’ahoval aj na špecifické ublíženie na tele, ktoré spočívalo v kastrácii osoby mužského pohlavia. Úvahu o tom, či ide o kvázi-vraždu budúcich generácii rozhodne nemožno opriet' o žiadne zdroje. To už vôbec neplatí vo vzt’ahu k zákazu obriezky, po ktorom siahol opät' cisár Hadrián. Ublíženie na tele bolo

continet, sed et id quod amatorium appellatur: sed hoc solum notatur in ea lege, quod hominis necandi causa habet. Sed ex senatus consulto relegari iussa est ea, quae non quidem malo animo, sed malo exemplo medicamentum ad conceptionem dedit, ex quo ea quae acceperat decesserit.

88 D. 48, 8, 3, 3 (Marci. 14 inst.). K odbornému výkladu pozri aj: WEXLER, P. History of Toxicology and Environmental Health: Toxicology in Antiquity - Volume II. London: Elsevier, 2015, s. 48.

89 AMIELAŃCZYK, c. d., s. 28-29. 
možné vo všeobecnosti subsumovat' pod delikt urážky (Nemci to výstižne nazývajú ako tzv. realinjurie).

Po vydaní Kornéliovho zákona došlo k miernej modifikácii dotknutej matérie ešte v dôsledku vydania Júliovho zákona o verejnom násilí, ktorý pripustil, aby ublíženia na tele bolo stíhané za predpokladu, ak šlo o následok špecifickej násilnej činnosti, napríklad v rámci zhromaždenia väčšieho počtu osôb (convocatis hominibus). ${ }^{90} \mathrm{Na}$ základe Júliovho zákona napokon došlo k sprísneniu dovtedajších predpisov o nosení zbrane na verejnosti.

90 D. 48, 6, 10, 1 (Ulp. 68 ad ed.): Hac lege tenetur et qui convocatis hominibus vim fecerit, quo quis verberetur et pulsetur, neque homo occisus sit. 